\title{
Heartland Virus and Hemophagocytic Lymphohistiocytosis in Immunocompromised Patient, Missouri, USA
}

\author{
Abigail L. Carlson, Daniel M. Pastula, \\ Amy J. Lambert, J. Erin Staples, \\ Atis Muehlenbachs, George Turabelidze, \\ Charles S. Eby, Jesse Keller, Brian Hess, \\ Richard S. Buller, Gregory A. Storch, \\ Kathleen Byrnes, Louis Dehner, \\ Nigar Kirmani, F. Matthew KuhImann
}

Heartland virus is a suspected tickborne pathogen in the United States. We describe a case of hemophagocytic lymphohistiocytosis, then death, in an immunosuppressed elderly man in Missouri, USA, who was infected with Heartland virus.

$\mathrm{H}$ eartland virus (HRTV; genus Phlebovirus, family Phenuiviridae [previously Bunyaviridae]) is a suspected tickborne pathogen in the United States (1). The virus was initially identified in 2009, and 9 cases of HRTV disease have been reported in the literature (2-5). Despite common features, the full spectrum of illness is unknown. We describe a fatal case of HRTV infection with hemophagocytic lymphohistiocytosis (HLH).

\section{The Case}

An elderly man from central Missouri, USA, came to the emergency department of a local hospital in June (year redacted) reporting 6 days of nausea, anorexia, and fatigue, followed by confusion and shortness of breath with cough. He denied fever, chills, or chest pain. He worked outdoors and had numerous tick exposures. His medical history included diabetes mellitus, chronic obstructive pulmonary disease, hypertension, coronary artery disease with ischemic cardiomyopathy, hypothyroidism, and rheumatoid arthritis; he was taking prednisone, methotrexate, and adalimumab.

Author affiliations: Veterans Affairs St. Louis Health Care System, St. Louis, Missouri, USA (A.L. Carlson); Washington University School of Medicine, St. Louis (A.L. Carlson, C.S. Eby, J. Keller, B. Hess, R.S. Buller, G.A. Storch, K. Byrnes, L. Dehner, N. Kirmani, F.M. Kuhlmann); Centers for Disease Control and Prevention, Fort Collins, Colorado, USA (D.M. Pastula,

A.J. Lambert, J.E. Staples); Centers for Disease Control and Prevention, Atlanta, Georgia, USA (D.M. Pastula, A. Muehlenbachs); Missouri Department of Health and Senior Services, Jefferson City, Missouri, USA (G. Turabelidze)

DOI: https://doi.org/10.3201/eid2405.171802
On initial examination, he was afebrile $\left(36.6^{\circ} \mathrm{C}\right)$, oriented only to year, and wheezed bilaterally on expiration. Laboratory results (Table 1) showed acute kidney injury, transaminitis, and mixed anion-gap metabolic acidosis and respiratory alkalosis. Initial complete blood count results showed normocytic anemia and thrombocytopenia. Total leukocyte count was within reference range, but lymphocyte count showed absolute lymphopenia. Troponin I was mildly elevated without electrocardiographic changes. Results of chest radiography and noncontrast computed tomography of the head were unremarkable. He was transferred to a tertiary care center for management of possible acute coronary syndrome and exacerbation of chronic obstructive pulmonary disease.

On post-symptom onset day (PSOD) 8, the patient became febrile $\left(38.9^{\circ} \mathrm{C}\right)$ and increasingly confused; we intubated him for airway protection. We empirically prescribed vancomycin, meropenem, ampicillin, and acyclovir for meningoencephalitis, as well as doxycycline for possible ehrlichiosis (Figure 1). We administered a platelet transfusion to complete a lumbar puncture safely. Lumbar puncture results revealed a mildly elevated cerebrospinal fluid (CSF) protein of $56 \mathrm{mg} / \mathrm{dL}$ and an unremarkable CSF glucose level of $64 \mathrm{mg} / \mathrm{dL}$. Specimen tubes 1 and 4 cell counts were, respectively, 14 and 0 leukocytes $/ \mu \mathrm{L}$ and 158 and 14 red blood cells $/ \mu \mathrm{L}$.

Initial testing for an infectious etiology of the illness was negative (Table 2), including a low positive rickettsia IgG titer, for which repeated testing was negative. Chest radiograph on PSOD 11 showed new multifocal infiltrates; a tracheal aspirate grew Stenotrophomonas maltophilia in culture, and we started levofloxacin. On the same day, we documented leukopenia, and a core bone marrow biopsy demonstrated hypocellularity for his age without blasts, dysplasia, or atypia. We were unable to obtain an aspirate sample. We suspected HLH; his ferritin had increased from $6,308 \mathrm{ng} / \mathrm{mL}$ on PSOD 8 to $53,666 \mathrm{ng} / \mathrm{mL}$ on PSOD 11 (reference 22-322 ng/dL). In addition, he had fever, leukopenia, thrombocytopenia, and hypertriglyceridemia (Table 1), meeting at that time 4 of 5 required diagnostic criteria by the HLH-2004 Histiocyte Society guidelines (6). We initiated presumptive HLH treatment with etoposide and highdose dexamethasone on PSOD 12. We stopped vancomycin and meropenem on PSOD 18 but restarted on PSOD 20 to 
Table 1. Selected laboratory values for immunocompromised patient infected with Heartland virus, Missouri, USA*

\begin{tabular}{|c|c|c|c|c|c|c|c|}
\hline \multirow[b]{2}{*}{ Test type } & \multirow[b]{2}{*}{ Reference range } & \multirow{2}{*}{$\begin{array}{c}4 \text { mo before } \\
\text { symptom onset }\end{array}$} & \multicolumn{5}{|c|}{ Post-symptom onset day } \\
\hline & & & 6 & 8 & 11 & 18 & 20 \\
\hline Leukocyte count, $\times 10^{3}$ cells $/ \mu \mathrm{L}$ & $3.8-9.8$ & 13.7 & 5.8 & 5.00 & 1.60 & 0.2 & NR \\
\hline Absolute neutrophil count, cells $/ \mu \mathrm{L}$ & $1,800-6,600$ & 7,400 & 5,000 & 4,100 & 1,200 & $<100$ & NR \\
\hline Absolute lymphocyte count, cells $/ \mu \mathrm{L}$ & $1,200-3,300$ & 3,300 & 700 & 500 & 400 & 100 & NR \\
\hline Hemoglobin, g/dL & $13.8-17.2$ & 12.1 & 11.8 & 10.5 & 7.1 & 7.0 & NR \\
\hline Hematocrit, \% & $40.7-50.3$ & 36.4 & 32.5 & 30.5 & 21.2 & 21.2 & NR \\
\hline Platelets, $\times 10^{3} / \mu \mathrm{L}$ & $140-440$ & 202 & 76 & 42 & 47 & 19 & NR \\
\hline International normalized ratio & $0.90-1.20$ & 1.06 & 1.0 & 1.19 & 1.15 & 1.47 & NR \\
\hline Partial thromboplastin time, $\mathrm{s}$ & $25.0-37.0$ & 46 & 40 & 53.1 & 56.6 & 39.7 & 38.3 \\
\hline Lactate dehydrogenase, units/L & $100-250$ & NR & 422 & 641 & 3040 & NR & NR \\
\hline Haptoglobin, mg/dL & $27-220$ & NR & NR & 208 & 227 & NR & NR \\
\hline Ferritin, $\mathrm{ng} / \mathrm{mL}$ & $22-322$ & NR & NR & 6,308 & 53,666 & NR & NR \\
\hline Fibrinogen, mg/dL & $170-400$ & NR & NR & NR & 215 & NR & NR \\
\hline Sodium, $\mathrm{mmol} / \mathrm{L}$ & $135-145$ & 139 & 128 & 141 & 141 & 138 & 136 \\
\hline Potassium, $\mathrm{mmol} / \mathrm{L}$ & $3.3-4.9$ & 4.0 & 5.1 & 5.9 & 5.1 & 5.5 & 4.8 \\
\hline Carbon dioxide, $\mathrm{mmol} / \mathrm{L}$ & $22-32$ & 27 & 13 & 15 & 16 & 21 & 25 \\
\hline Blood urea nitrogen, $\mathrm{mg} / \mathrm{dL}$ & $8-25$ & 16 & 90 & 63 & 94 & 60 & 50 \\
\hline Creatinine, $\mathrm{mg} / \mathrm{dL}$ & $0.70-1.30$ & 1.31 & 3.38 & 1.75 & 4.74 & $1.95 \dagger$ & $1.80 \dagger$ \\
\hline Troponin I, ng/mL & $0.00-0.03$ & 2.55 & 0.76 & 0.27 & NR & NR & NR \\
\hline Cholesterol, total, $\mathrm{mg} / \mathrm{dL}$ & $0-200$ & 258 & 115 & NR & NR & NR & NR \\
\hline Triglycerides, mg/dL & $0-150$ & 426 & 532 & NR & NR & NR & NR \\
\hline Aspartate aminotransferase, units/L & $11-47$ & 32 & 231 & 147 & 684 & NR & 146 \\
\hline Alanine aminotransferase, units/L & $7-53$ & 17 & 186 & 112 & 118 & NR & 52 \\
\hline Alkaline phosphatase, units/L & $38-126$ & 85 & 60 & 65 & 111 & NR & 65 \\
\hline Bilirubin, total, $\mathrm{mg} / \mathrm{dL}$ & $0.3-1.1$ & 0.3 & 0.1 & 0.2 & 0.2 & NR & 0.7 \\
\hline Bilirubin, direct, mg/dL & $0.0-0.3$ & 0.1 & 0.1 & NR & 0.2 & NR & NR \\
\hline Amylase, units/L & $28-100$ & NR & 234 & NR & NR & NR & NR \\
\hline Lipase, units/L & $0-99$ & NR & 578 & NR & NR & NR & NR \\
\hline $\mathrm{pH}$ & $7.35-7.45$ & NR & 7.31 & 7.17 & 7.24 & 7.42 & 7.32 \\
\hline $\mathrm{P}_{\mathrm{a}} \mathrm{CO}_{2}, \mathrm{~mm} \mathrm{Hg}$ & $35-45$ & NR & 21 & 41 & 38 & 36 & 47 \\
\hline $\mathrm{P}_{\mathrm{a}} \mathrm{O}_{2}, \mathrm{~mm} \mathrm{Hg}$ & $80-105$ & NR & 125 & 93 & 108 & 159 & 96 \\
\hline Temperature, ${ }^{\circ} \mathrm{C}$ & $35.5-38.3$ & NR & 36.6 & 38.9 & 38.2 & 37.3 & 35.4 \\
\hline $\mathrm{F}_{\mathrm{i}} \mathrm{O}_{2}$ & 0.21 & NR & 0.40 & 0.40 & NR & 0.40 & NR \\
\hline
\end{tabular}

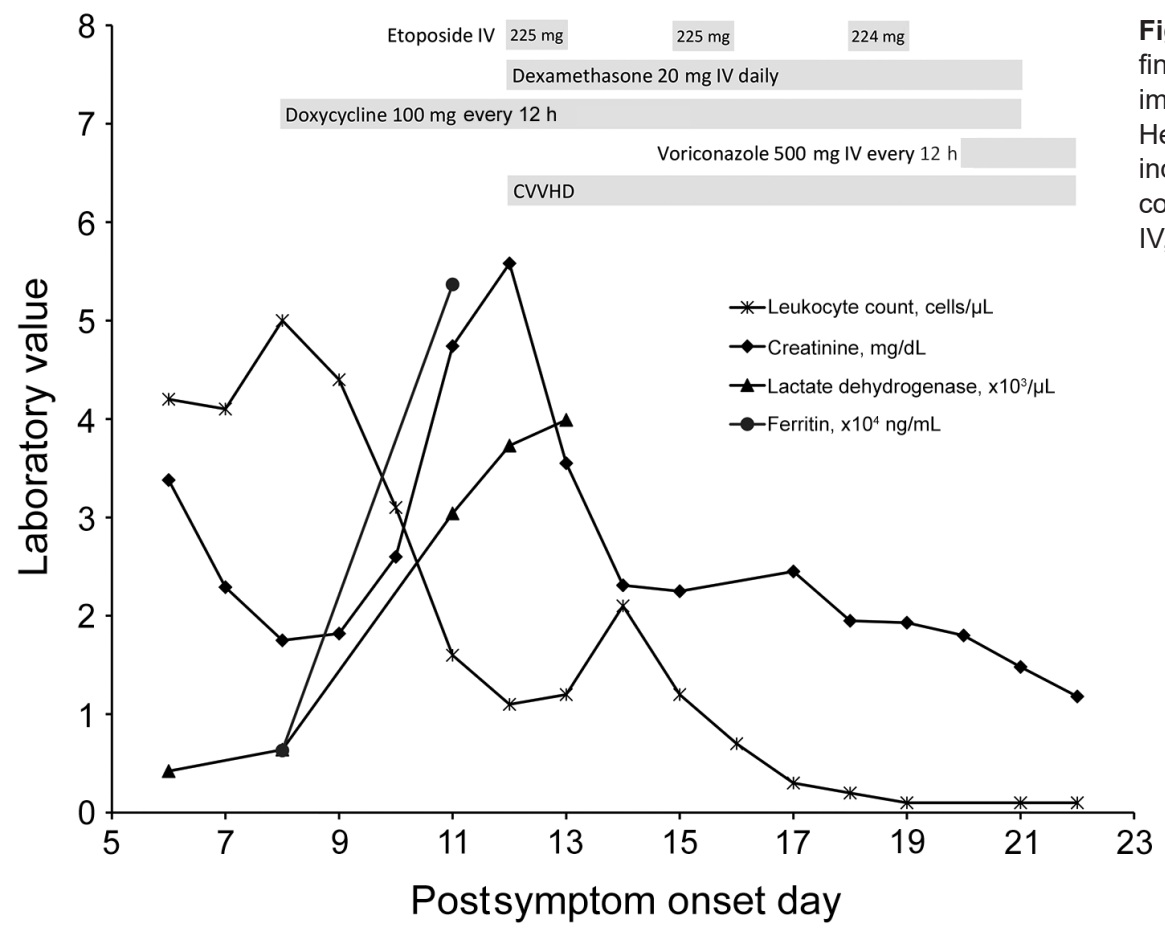

Figure 1. Chronology of selected laboratory findings and therapeutic interventions for immunocompromised patient infected with Heartland virus, Missouri, USA. Gray bars indicate treatments administered. CVVHD, continuous veno-venous hemodialysis; IV, intravenous. 
Table 2. Infectious disease testing of immunocompromised patient infected with Heartland virus, Missouri, USA*

\begin{tabular}{|c|c|c|}
\hline PSOD & Test and sample type & Result \\
\hline 6 & Aerobic culture, urine & Nonsignificant growth \\
\hline \multirow[t]{4}{*}{7} & Rickettsia SFG IgG, serum & $1: 64$ (normal <1:64) \\
\hline & Rickettsia SFG IgM, serum & $<1: 64$ (normal <1:64) \\
\hline & HIV 1, 2 antibody, serum & Negative \\
\hline & Epstein-Barr viral capsid antibody, IgM, serum & Nonreactive \\
\hline \multirow[t]{10}{*}{8} & Aerobic and anaerobic culture, blood $\times 2$ & No growth \\
\hline & Ehrlichia and Anaplasma PCR, blood & Negative \\
\hline & Enterovirus RT-PCR, CSF & Negative \\
\hline & Cytomegalovirus PCR, CSF & Negative \\
\hline & West Nile virus IgG, CSF & Negative \\
\hline & West Nile virus IgM, CSF & Negative \\
\hline & Cryptococcal antigen, CSF & Negative \\
\hline & Fungal culture, CSF & No growth \\
\hline & Aerobic culture, CSF & No growth \\
\hline & Fungal culture, blood & No growth \\
\hline \multirow[t]{3}{*}{9} & Aerobic culture, tracheal aspirate & Aspergillus terreus \\
\hline & Aerobic culture, urine & No growth \\
\hline & Aerobic and anaerobic culture, blood $\times 2$ & No growth \\
\hline \multirow[t]{9}{*}{10} & Aerobic and anaerobic culture, blood $\times 2$ & No growth \\
\hline & Acid-fast bacilli culture, blood & No growth \\
\hline & Fungal culture, blood & No growth \\
\hline & Ehrlichia and Anaplasma PCR, blood & Negative \\
\hline & Cytomegalovirus PCR, blood & Not detected \\
\hline & Histoplasma antigen, urine & Negative \\
\hline & Aspergillus galactomannan antigen, blood & Negative \\
\hline & Rickettsia SFG IgG, serum & $<1: 64$ (normal <1:64) \\
\hline & Rickettsia SFG IgM, serum & $<1: 64$ (normal <1:64) \\
\hline 11 & Aerobic culture, tracheal aspirate & $\begin{array}{l}\geq 100,000 \text { colonies } / \mathrm{mL} \text { Stenotrophomonas } \\
\text { maltophilia; } \geq 100,000 \text { colonies/mL yeast }\end{array}$ \\
\hline 14 & Heartland virus RT-PCR, blood & Positive \\
\hline \multirow[t]{3}{*}{20} & Aerobic and anaerobic culture, blood & Candida albicans \\
\hline & Fungal culture, blood & No growth \\
\hline & Cytomegalovirus PCR, blood & Not detected \\
\hline Autopsy & $\begin{array}{l}\text { Heartland virus RT-PCR, blood } \\
\text { Heartland virus RT-PCR, lymph node } \\
\text { Heartland virus RT-PCR, spleen }\end{array}$ & $\begin{array}{l}\text { Positive } \\
\text { Positive } \\
\text { Positive }\end{array}$ \\
\hline
\end{tabular}

treat suspected sepsis after hypothermia and hypotension developed. The same day, we started voriconazole therapy to treat the patient for Aspergillus terreus identified from a sputum culture taken on PSOD 9. A. terreus had been deemed a contaminant, but we subsequently chose to treat it as a pathogen because of the patient's leukopenia and respiratory failure. On PSOD 20, the Centers for Disease Control and Prevention (Fort Collins, CO, USA) notified the clinical care team that a blood sample obtained on PSOD 14 was positive for HRTV RNA) by reverse transcription PCR (RT-PCR) and positive for HRTV neutralizing antibodies by plaque reduction neutralization test (titer 10). Because of the patient's clinical decline, his family elected to transition to comfort care, and he died on PSOD 22.

Autopsy revealed splenomegaly and erythrophagocytosis with histiocytic hyperplasia in bone marrow, spleen, and lymph nodes, consistent with HLH. In addition, disseminated angioinvasive candidiasis was seen, and Candida albicans was isolated from blood cultures previously taken on PSOD 20. Central nervous system (CNS) findings included multiple brain infarcts without evidence of meningitis or encephalitis. Grocott's methenamine silver stains of the occipital lobe were negative for yeast. All autopsy tissues were negative by HRTV immunohistochemistry (IHC) performed as previously described (4). However, the earlier bone marrow core biopsy had extensive HRTV antigen identified by retrospectively performed IHC (Figure 2). Autopsy specimens of blood, lymph nodes, and spleen were positive for HRTV RNA by RT-PCR.

The CSF (tube 4) and blood samples obtained on PSOD 8 were analyzed retrospectively for HRTV by using real-time PCR assay primers and probes as previously described (3). HRTV RNA was detected in both specimens, although at substantively higher levels in the blood (cycle threshold 20) than in the CSF (cycle threshold 32).

\section{Conclusions}

HRTV was first identified in 2009, when 2 Missouri farmers who had been bitten by ticks were admitted to a hospital for fever, fatigue, and anorexia (3). Since then, descriptions of $\geq 7$ additional cases, including 2 deaths, have been published $(2,4,5)$. HRTV is believed to be transmitted by 


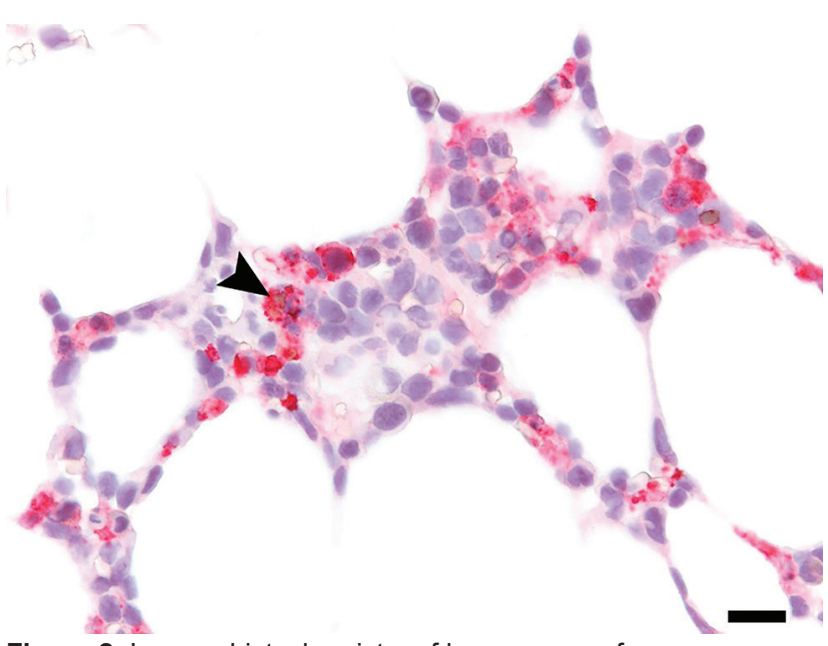

Figure 2. Immunohistochemistry of bone marrow from immunocompromised patient infected with Heartland virus (HRTV), Missouri, USA. Testing of biopsied sample from postsymptom onset day 11 shows extensive positive staining for HRTV antigen, including erythrophagocytosis by an HRTV-antigenpositive cell (arrowhead). Scale bar indicates $20 \mu \mathrm{m}$.

the lone star tick (Amblyomma americanum) and may be present in various mammals (7-9). This patient's condition was similar to those described in the literature, who had fatigue, anorexia, thrombocytopenia, and transaminitis at hospital admission.

HLH is a syndrome of T-cell and macrophage hyperactivation, leading to elevated cytokines and end-organ dysfunction (10). Secondary HLH is often precipitated by infection, although malignancy and autoimmune diseases are also common precipitants. The HLH-2004 Histiocyte Society guidelines provide 8 diagnostic criteria for the syndrome, 5 of which must be met to establish the diagnosis (6). However, these guidelines were written on the basis of pediatric case series, and controversy remains regarding their sensitivity, specificity, and applicability in adults with HLH (11-13). We identified 4 HLH criteria at the time of treatment: fever, bicytopenia, hypertriglyceridemia, and hyperferritinemia. Two additional criteria, splenomegaly and hemophagocytosis, were documented at autopsy. Tests were not done for natural killer cell activity or soluble CD25 receptor levels.

We cannot directly prove that HRTV infection led to HLH in this case; however, there is a probable association. First, 4 HLH criteria were met on PSOD 8, before the identification of other infections (e.g., S. maltophilia pneumonia and candidemia), although these conditions may have contributed to the HLH clinical course once present. Second, HRTV without Candida spp. was detectable in the bone marrow at the time HLH was diagnosed, and erythrophagocytosis by HRTV antigen-positive cells in bone marrow were seen in the retrospective IHC analysis
(Figure 2). Finally, 1 prior HRTV case report also detected hemophagocytosis in a lymph node (4).

This patient's severe disseminated HRTV infection may have been exacerbated by his immunosuppressant medications, co-infections, or underlying conditions and could have been further exacerbated by etoposide and dexamethasone treatment. Multiple underlying conditions were also noted in another reported patient with fatal HRTV disease (4). We detected HRTV RNA in this patient's CSF by RT-PCR, which may reflect CNS dissemination or may be from contamination with blood during the lumbar puncture. Further investigation is necessary to determine if HRTV can invade the CNS.

Increasing recognition of HRTV disease will support generating further data on clinical characteristics of and risk factors for higher severity. Clinicians should be alert to the possibility of severe HRTV disease, including the potential development of HLH, in persons who are immunosuppressed, have multiple concurrent conditions, or both. Early recognition of $\mathrm{HLH}$, treatment of patients diagnosed with this condition, and referral to tertiary care centers should be considered in these situations.

\section{About the Author}

Dr. Carlson is a physician who specializes in infectious diseases and is an associate hospital epidemiologist at the Veterans Affairs St. Louis Health Care System and Washington University School of Medicine in St. Louis, Missouri. Her research interests include antimicrobial stewardship, infection control, and health security.

\section{References}

1. Zhu Y, Wu Y, Chai Y, Qi J, Peng R, Gao GF. The postfusion structure of the Heartland virus Gc glycoprotein supports taxonomic separation of the Bunyaviral families Phenuiviridae and Hantaviridae. J. Virol. 2018;92:e01558-17. http://dx.doi.org/ 10.1128/JVI.01558-17

2. Pastula DM, Turabelidze G, Yates KF, Jones TF, Lambert AJ, Panella AJ, et al.; Centers for Disease Control and Prevention. Notes from the field: Heartland virus disease-United States, 2012-2013. MMWR Morb Mortal Wkly Rep. 2014;63:270-1.

3. McMullan LK, Folk SM, Kelly AJ, MacNeil A, Goldsmith CS, Metcalfe MG, et al. A new phlebovirus associated with severe febrile illness in Missouri. N Engl J Med. 2012;367:834-41. http://dx.doi.org/10.1056/NEJMoa1203378

4. Muehlenbachs A, Fata CR, Lambert AJ, Paddock CD, Velez JO, Blau DM, et al. Heartland virus-associated death in Tennessee. Clin Infect Dis. 2014;59:845-50. http://dx.doi.org/10.1093/ cid/ciu434

5. Fill MA, Compton ML, McDonald EC, Moncayo AC, Dunn JR, Schaffner W, et al. Novel clinical and pathologic findings in a Heartland virus-associated death. Clin Infect Dis. 2016;64:510-2. http://dx.doi.org/10.1093/cid/ciw766

6. Henter JI, Horne A, Aricó M, Egeler RM, Filipovich AH, Imashuku S, et al. HLH-2004: diagnostic and therapeutic guidelines for hemophagocytic lymphohistiocytosis. Pediatr Blood Cancer. 2007;48:124-31. http://dx.doi.org/10.1002/ pbc. 21039 
7. Savage HM, Godsey MS Jr, Lambert A, Panella NA, Burkhalter KL, Harmon JR, et al. First detection of heartland virus (Bunyaviridae: Phlebovirus) from field collected arthropods. Am J Trop Med Hyg. 2013;89:445-52. http://dx.doi.org/10.4269/ ajtmh.13-0209

8. Bosco-Lauth AM, Panella NA, Root JJ, Gidlewski T, Lash RR, Harmon JR, et al. Serological investigation of heartland virus (Bunyaviridae: Phlebovirus) exposure in wild and domestic animals adjacent to human case sites in Missouri 2012-2013. Am J Trop Med Hyg. 2015;92:1163-7. http://dx.doi.org/10.4269/ ajtmh.14-0702

9. Riemersma KK, Komar N. Heartland virus neutralizing antibodies in vertebrate wildlife, United States, 2009-2014. Emerg Infect Dis. 2015;21:1830-3. http://dx.doi.org/10.3201/eid2110.150380

10. McClain KL, Allen CE. Inflammatory and malignant histiocytosis. In: Lichtman MA, Kipps TJ, Seligsohn U, Kaushansky K, Prchal JT, editors. Williams Hematology, 8th edition. New York: McGraw-Hill; 2010. [cited 2017 Oct 30] http://accessmedicine.mhmedical.com/content.aspx?bookid=358\&s ectionid $=39835892$

11. Li J, Wang Q, Zheng W, Ma J, Zhang W, Wang W, et al. Hemophagocytic lymphohistiocytosis: clinical analysis of 103 adult patients. Medicine (Baltimore). 2014;93:100-5. http://dx.doi.org/10.1097/MD.0000000000000022

12. Otrock ZK, Eby CS. Clinical characteristics, prognostic factors, and outcomes of adult patients with hemophagocytic lymphohistiocytosis. Am J Hematol. 2015;90:220-4. http://dx.doi.org/10.1002/ajh.23911

13. Ramos-Casals M, Brito-Zerón P, López-Guillermo A, Khamashta MA, Bosch X. Adult haemophagocytic syndrome. Lancet. 2014;383:1503-16. http://dx.doi.org/10.1016/ S0140-6736(13)61048-X

Address for correspondence: Abigail L. Carlson, Washington University School of Medicine, 4523 Clayton Ave, Campus Box 8051, St. Louis, MO 63110, USA; email: alcarlson@wustl.edu

\section{August 2014: Vectorborne Diseases}

- Leptospirosis-Associated Hospitalizations, United States, 1998-2009

- Independent Origin of Plasmodium falciparum Antifolate SuperResistance, Uganda, Tanzania, and Ethiopia

- Global and Local Persistence of Influenza $\mathrm{A}(\mathrm{H} 5 \mathrm{~N} 1)$ Virus

- Human Exposure to Live Poultry and Psychological and Behavioral Responses to Influenza A(H7N9), China

- Rapid Whole-Genome Sequencing for Surveillance of Salmonella enterica Serovar Enteritidis

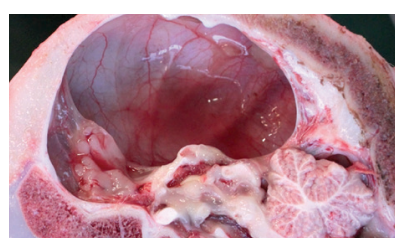

- Novel Reassortant Influenza A(H5N8) Viruses in Domestic Ducks, Eastern China

- Antibodies against MERS Coronavirus in Dromedary Camels, Kenya, 1992-2013
- Borrelia crocidurae Infection in Acutely Febrile Patients, Senegal

- Shelter Dogs as Sentinels for Trypanosoma cruzi Transmission across Texas, USA

- Natural Intrauterine Infection with Schmallenberg Virus in Malformed Newborn Calves

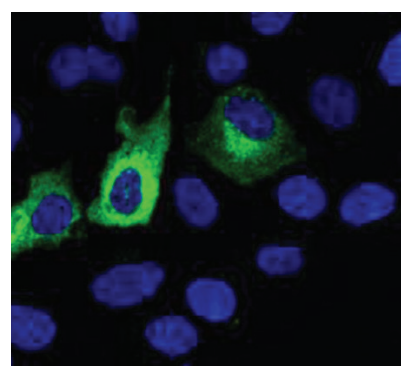

- Role of Migratory Birds in Spreading CrimeanCongo Hemorrhagic Fever, Turkey

- Isolation of MERS Coronavirus from Dromedary Camel, Qatar, 2014

- New Introductions of Enterovirus 71 Subgenogroup C4 Strains, France, 2012
- Rapid Detection, Complete Genome Sequencing, and Phylogenetic Analysis of Porcine Deltacoronavirus

- Geographic Distribution of MERS Coronavirus among Dromedary Camels, Africa

- Human Infections with Borrelia miyamotoi, Japan

- Co-circulation of Dengue and Chikungunya Viruses, Al Hudaydah, Yemen, 2012

- Antibodies against Severe Fever with Thrombocytopenia Syndrome Virus in Healthy Persons, China, 2013

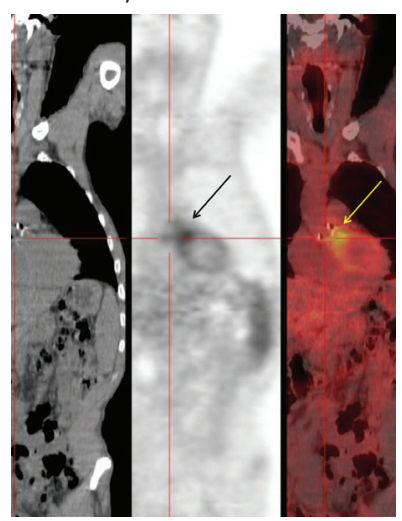

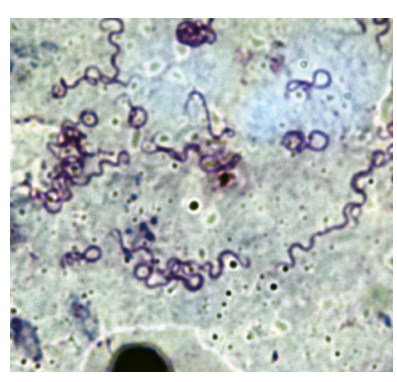

- Severe Fever with Thrombocytopenia Syndrome Virus in Ticks Collected from Humans, South Korea, 2013

- Infection with Possible Precursor of Avian Influenza A(H7N9) Virus in a Child, China, 2013

- Dengue Virus Transmission by Blood Stem Cell Donor after Travel to Sri Lanka, 2012

- Severe Murine Typhus with Pulmonary System Involvement

- Detection of East/Central/ South African Genotype of Chikungunya Virus in Myanmar, 2010

- Pulmonary Infection and Colonization with Nontuberculous Mycobacteria, Taiwan, 2000-2012 